Canadian Journal of Applied Linguistics

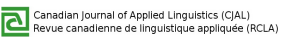

Revue canadienne de linguistique appliquée

Deterritorializing Language, Teaching, Learning, and Research. Deleuzo-Guattarian Perspectives on Second Language

Education

\title{
Magali Forte
}

Volume 24, numéro 3, automne 2021

URI : https://id.erudit.org/iderudit/1084817ar

DOI : https://doi.org/10.37213/cjal.2021.31452

Aller au sommaire du numéro

Éditeur(s)

University of New Brunswick

ISSN

1920-1818 (numérique)

Découvrir la revue

Citer ce compte rendu

Forte, M. (2021). Compte rendu de [Deterritorializing Language, Teaching,

Learning, and Research. Deleuzo-Guattarian Perspectives on Second Language

Education]. Canadian Journal of Applied Linguistics / Revue canadienne de

linguistique appliquée, 24(3), 207-209. https://doi.org/10.37213/cjal.2021.31452 
Bangou, F., Waterhouse, M., \& Fleming, D. (2020). Deterritorializing Language, Teaching, Learning, and Research. Deleuzo-Guattarian Perspectives on Second Language Education. Brill Sense.

Reviewer: Magali Forte, Simon Fraser University, British Columbia, Canada

Deterritorializing Language, Teaching, Learning, and Research is a timely contribution to the growing body of texts that put Deleuzo-Guattarian concepts to work in the fields of second language education (SLE) and language teacher education (LTE). The central concept of deterritorialization refers to the authors' engagement in questioning the conventional ways in which we inquire about, teach, learn and live language education. In this four-part edited volume, each chapter disrupts old concepts, creates new ones, and maps unexplored paths in the fields of language curriculum, language learners' identities, literacies, and LTE.

In the introduction, Waterhouse and Bangou use the popular Deleuzo-Guattarian concept of rhizome, which takes after the underground plant stem whose roots and shoots grow horizontally and irregularly, to offer different and unconventional ways of thinking/reading. For instance, they suggest readers look for these central DeleuzoGuattarian concepts in non-linear ways: rhizome, affect, assemblage/agencement, de/re/territorialization, difference, the virtual, and desire. They also propose tracking broader recurring ideas emerging throughout the chapters, such as materialist undoings of the humanist subject, rhizomatic assemblages/agencements in research methodologies, affective relationality, and multiplicity/difference.

Part I of the book focuses on deterritorializing language curriculum. In Chapter 1, Waterhouse weaves the six principles of the rhizome together with data excerpts from a study conducted in adult immigrant ESL classrooms. She offers the concept of rhizocurriculum to disrupt the expected and conventional view of the language curriculum. She thereby recasts the teacher/learner relationship as central and as a "co-becoming, a transformative movement that cannot be neatly identified and whose endpoint cannot be defined" (p. 31). She encourages teachers and researchers to remain open to these unexpected and transformative movements in practice and to reflect on their potential to disrupt carefully planned lessons. The fact that we cannot know in advance everything that might be produced in this view of ESL education opens a promising way out of prescriptive pedagogical spaces.

In Part II, focusing on deterritorializing language learners' identity, several contributors offer different ways of conceiving the human subject in SLE. In Chapter 2, Fleming puts to work the concept of "becoming woman," revisiting data from a previous study conducted while teaching English to immigrant learners in Canada. Taking gender into account this time, he maps the transformations that happened in the identity trajectories of Punjabi speakers who immigrated from India. Fleming follows the lines of deterritorialization traced by women participants who shared how liberating their experiences had been. A role shift happened within their families and their relations in terms of access to "employment, education, marriage choice, reproductive rights, dress and [...] the public sphere" (p. 51) and enabled a powerful disruption in their identities, previously considered as stable. In Chapter 3, Piccardo presents a convoluted map of the development of plurilingualism and a view of what it could become, mobilizing three 
concepts borrowed from the fields of sociology and philosophy: liquidity, complexity and difference. Proposing the concept of plurilanguaging, she argues that the 3.0 plurilingual learner will need to be open to creative and blended forms of language learning that disrupt discrete views of language, culture and identity. According to her, this has the potential to put the ideal of the native speaker away, once and for all. Putting to work the DeleuzoGuattarian concepts of minor and major languages in Chapter 4, Bradley articulates a different perspective on Nerrière's tool of communication, Globish, turning it into a war machine that could dismantle the powerful and privileged status the "Standard English" construct holds in our capitalist societies (p. 104). Through his analysis of the influence of Globish in Japan, Bradley, using the Deleuzo-Guattarian concept of desire, highlights some of its shortcomings, in particular, the impossibility for Globish (or any language) to exist without ties to an identity or a culture (p. 90). Bradley calls attention to the deterritorializing potential of Globish to dismantle the colonial forces English language and culture have embodied and exerted for hundreds of years. In Chapter 5, Ravindran and Ilieva trouble existing representations of international graduates of a Teaching English as an Additional Language Masters' program. Doing so, they offer a novel and convincing view of agency as dynamic and not grounded in human individuals but rather as emerging from sociomaterial assemblages. They mobilize the Deleuzo-Guattarian notions of desire and becoming, and Massumi's take on affect, to trace "emergent forms of subjectivity" (p. 11 ), thereby challenging a homogenous view of identity. New promising and liberating pedagogical avenues appear when opening to the unpredictability of the "entanglement of human and material elements" (p. 118).

Part 3 explores the potential of deterritorializing literacies. In Chapter 6 , as she maps the "affective connections" (p. 141) and possibilities of source-based writing for L2 learners in an English for Academic Purposes program, Vasilopoulos disrupts the conventional view of plagiarism. She calls for an opening in literacy and language teachers' gaze to take into consideration the full (and often invisible) process L2 students engage in when writing with digital tools. This leads to questioning a common and inadequate focus on finished products in the digitally mediated writing classroom. Building on the concept of "virtual plagiarism," Vasilopoulos encourages instructors to embrace the principle of relationality central to Deleuzian philosophy in order to view writing in a different light. This entails a decentering of the human subject to take into account the myriad digital tools involved in any writing assemblage. In Chapter 7, Bastien-Valenca follows rhizomatic literacy practices within a family literacy intervention program in Ontario. Bastien-Valenca shares five vignettes that focus on an unexpected effect of the program: moments of language learning not only for children but also for newcomer parents. The concepts of rhizo-teaching and rhizo-home-visiting surface with the last vignette. Through purposeful questioning, Bastien-Valenca raises thought-provoking questions that readers, becoming a part of the research/writing assemblage, can answer in different ways.

Part IV focuses on deterritorializing language teacher education. In Chapter 8, Bangou asks how teacher education might exist in Computer Assisted Language Learning (CALL). Rather than describing an observable reality, he engages with the DeleuzoGuattarian philosophy of immanence to speculate and imagine what might be. The emerging concept of Teacher Becoming in CALL troubles a fixed representation of L2 teacher education while inviting the reader to open up to unpredictability in 
learning/teaching practices. Presenting data in the form of vignettes, Bangou offers an inspiring example of how connections might happen while sharing a different perspective on L2 teacher education in CALL. In Chapter 9, Emke presents a different way of conducting doctoral research. Instead of following the linear and product-oriented conventional trajectory, she suggests paying attention to the creative opportunities that arise when one considers the "multiplicity of situated assemblages of human and nonhuman factors" (p. 216) that make a doctoral thesis. In her own study, she went beyond "received" and "embedded" views of the human-technology relation which position the human as the subject and technology as a tool. Focusing instead on a relational view of human-technology assemblages, she asks what human/non-human entanglements might produce that we would not have noticed from an anthropocentric perspective. The concept of Twitter machine thereby emerges to invite new ways of envisioning networked learning in freelance language teachers' professional development on/with/through Twitter.

In the last chapter of the book, called "Intermezzo" to highlight the co-editors" effort to "open another space for readers to think with/in the possibilities" (p. 224) that lie beyond the book, Bangou, Waterhouse and Fleming insist that this collection is but ONE "singular actualization" (p. 225) of rhizomatic connections made between DeleuzoGuattarian theory and the contributors' writing assemblages. Doing so, they invite readers to be a part of it and to follow new connections and lines of flight within their own thinking/writing/research assemblages.

This is an inspiring and thought-provoking resource for researchers, students and teachers working in the fields of SLE and LTE as it explores the intersections between language, teaching, learning, and research while challenging anthropocentric views of language education in diverse settings (university, family, online, in-person, etc.). Researchers who engage with Deleuzo-Guattarian theories in other fields (such as philosophy or cultural studies, for example) can also find in this book inspiring theorizing that might not have been explored in their own fields, as pointed out in the foreword. Overall, this book is a noteworthy collection of research inquiries that compel every reader to think deeply about extraordinary ways to conduct and live language education. 